Egypt. J. of Appl. Sci, 36 (3) 2021

\title{
BIO-AGRICULTURE AND ITS EFFECT ON THE PRODUCTIVITY AND QUALITY OF PEANUTS (ARACHIS HYPOGAEA) UNDER NORTH SINAI CONDITION - EGYPT.
}

\author{
Mahmoud A.M. El-Sayed \\ Soil Fertility and Microbiology Department, Desert Research Center, \\ El-Mataria, Cairo, Egypt \\ Email - mahalyeg@yahoo.com, mahalyeg30@gmail.com
}

Key Words: Olive waste compost, Biomagic liquid fertilizer, Rhizobium, Azotobacter, Phosphorous dissolving bacteria (PDB), Peanut (Arachis hypogaea), North Sinai.

\begin{abstract}
A field experiment was conducted at Baloza Experimental Station of the Desert Research Center (DRC) in North Sinai - Egypt. The GIS indices of this location are N3101-43.0296- E 32035-28.0431) in two successive summer seasons of 2015 and 2016. The most prominent objectives of the current work can be portrayed in recycling olive oil extraction waste, verifying the role played by bio-fertilizers in utilizing the manufactured compost, diminishing the pollution brought about by mineral fertilizers, testing the nutritional function of Biomagic to peanut plants, and figuring out the best combination treatment among all these production tools that give the highest possible peanut seed content at the best possible quality under the conditions of North Sinai of Egypt. The applied treatments involved applying olive compost vs. no application, spraying Biomagic nutrient solution vs. no spraying, inoculating the seeds with Rhizobium (the control treatment) vs. inoculating the seeds with Azotobacter and phosphorous dissolving bacteria both applied separately or together in a mixed inoculation. These treatments were arranged in a factorial experiment in three randomized complete blocks. Mean values were verified from each other using Dunkan least significant range (LSR) and denoted by alphabetical letters. In that, any two mean values sharing an alphabet letter are not significantly different. The superior combination treatment is to be composed of applying compost $\mathrm{x}$ canopy spraying $\mathrm{x}$ biofertilizers, shows that the best combination treatment was composed from applying compost + spraying plants' canopy with Biomagic $\mathrm{x}$ inoculating the seeds with a mixture of Azotobacter and PDB in both years of study. This treatment could significantly proliferate better growth conditions in the rhizosphere that nourished the most vigorous microbiological growth. It could lead to better peanut plants vegetative growth. It could also lead to the best significant peanut seed content with best quality. Detailed effects of all applied factors can be found in the research.
\end{abstract}




\section{INTRODUCTION}

Balasubramanian and Palaniappan (1994) reported that use of microbial inoculants in combination with FYM favored groundnut production. Dharma (1996) found that FYM stimulated the activities of microorganisms that render plant nutrients available to crops. Ahmed $\boldsymbol{e t}$ al. (1997) stated that the highest dry matter accumulation, kernel yield and oil content were achieved by fertilization with farmyard manure. Ismail et al. (1998) reported significant increase in organic C, available $\mathrm{N}$ and $\mathrm{P}$ content of the soil with application of FYM possibly due to the increase in decomposition product of organic matter. Application of FYM at 10 to 15 tha $^{-1}$ increased the pod and seed yields and improved groundnut yield parameters as shelling percentage and 100 seed weight (Subrahmaniyan et al., 2000). Application of FYM at 21.9 tha-1 produced the highest DMP, pod yield and haulm yield, and gave higher net return and BCR (Chandrasekaran et al., 2007). Veeramani et al. (2012) reported that excessive application of nitrogen and potassium to groundnut often resulted in excessive vegetative growth. Considering the availability of major elements in the soil and quantum of losses due to leaching and/or fixation of individual elements expected, a proper method and time of nutrient application deem necessary to increase pod yield. OMs effectively contribute to plant growth.

El- Boraie et al. (2009) examined the influence of biofertilization under drip irrigation system on peanut yield and yield components. They also studied soil microbiological properties. They found that seed inoculation with Rhizobium highly increased nodules number more than Azotobacter, which decreased the decomposition of organic matter in the soil. The highest significant pod yield was obtained from applying $983.73 \mathrm{~mm}$ irrigation quantity (Q ), which was daily applied to plants, inoculating the seeds with a mixture of Rhizobium + Azotobacter chroococcum + Bacillus megaterium. Gharib et al. (2009) studied the effect of bacterial inoculation with Rhizobium leguminoarum bv. phaseoli and two strains of Azotobacter chroococcum and Bacillus megaterium as a biofertilizers on nodulation, $\mathrm{N}_{2}$-fixation, population of rhizosphere microorganism, NPK-content, and yield of two snap bean cultivars under $25 \%$ of the recommended dose of NPK chemical fertilizers. They found that mixed $(\mathrm{Rh}+\mathrm{AZ}+\mathrm{BM})$ inoculation treatments in the presence of $25 \%$ of the recommended dose of chemical NPK fertilizers had highly significant effects on snap been growth, nodulation, and $\mathrm{N}_{2}$-fixation. Inoculation with Rhizobium + Bacillus megaterium (BM3) with $25 \%$ of the recommended NPK dose significantly increased all traits of vegetative growth, yield and its components and pods characteristics.

Foliar feeding of a nutrient promoted root absorption of the same nutrient or other nutrients through improving root growth and increasing 
nutrients uptake (El-Fouly and El-Sayed, 1997). In addition, supply of $\mathrm{N}$ either from foliar sources or symbiotic fixation resulted in greater nitrogen content in the leaf canopy and increased biomass production. Foliar feeding is often the most effective and economical way to correct plant nutrient deficiencies. Foliar application of nutrients improved nutrient utilization and lowered environmental pollution through reducing the amounts of fertilizers added to soil (Abou-El-Nour 2002). Hanan et al. (2015) experimented with urea-N rates and application routes; soil or foliar, with or without compost on the production of peanut (Arachis hypogaea L.). They indicated that the application of compost increased weight of peanut seeds and pods yields. They also recommended soil application to foliar application. Tamer (2018) reported that Biomagic is a microbial bioactive non hormonal foliar spray. It has amino acids thiamin, cysteine, glycine, histidine, isoleucine, leucine, lysine, phenylalanine, threonine, tryptophane, tyrosine, and valine. It contains vitamins thiamine, biotiene, choline, folic acid, niacin, pantothenic, pyrodxine, and rhiboflavin. It contains $\mathrm{N}, \mathrm{P}, \mathrm{K}$, and $\mathrm{Mg}$. It also contains micro nutrients $\mathrm{Fe}, \mathrm{Zn}, \mathrm{Mn}, \mathrm{Cu}, \mathrm{B}, \mathrm{Mo}, \mathrm{Cd}$, and $\mathrm{Ni}$. As described, Biomagic is a readymade product that can be sprayed on plants to promote their growth.

The objectives of the current work can be portrayed as a) Verifying the role played by bio-fertilizers in utilizing OMs to avoid the deteriorating effects of mineral fertilizers, b) Diminishing the pollution brought about by mineral fertilizers by recruiting organic compost, and c) Figuring out the best combination treatment among organic and biological fertilizers that gives the highest possible seed yield of peanut with best quality measures under the conditions of North Sinai of Egypt.

\section{Experimental site:}

\section{MATERIALS AND METHODS}

A field experiment was conducted at Baloza Experimental Station of the Desert Research Center (DRC) in North Sinai, Egypt. The GIS indices of this location are N3101-43.0296- E 32035-28.0431) in two successive seasons of 2015 and 2016.

The target of this study was to estimate the mutual effects of three basic factors. The first belonged to the application of OM $(\mathrm{OM})$ versus no application (OM0 vs. OM1). The applied OM consisted of olive processing byproducts added to rice straw at 1: 2 ratio). The resultant compost was added to the soil at the rate of 5 tons fed ${ }^{-1}$ three weeks before planting. The second factor belonged to foliar fertilization with a non-hormonal biostimulant; i.e. Biomagic (M). The third factor belonged to biological inoculation (I) with Rhizobium leguminosarum, Azotobacter chrococcum, and Bacillus megaterium all applied separately, and in addition to applying a mixture of the latter two. Peanut seeds were coated with these inoculants by 
using $1 \%$ carboxy-methyl-cellulose (CMC) as an adhesive agent, and airdried prior to seeding (Hameeda, 2008). One month after seeding, half the plants were sprayed with Biomagic.

Biomagic is a microbial bioactive non hormonal foliar spray. It was kindly provided by Prof. Dr. Mohamed Abd El Fattah El-Sibaie (Prof. of Agric. Microbiology Dept. Desert Research Center). It has a pH 5.5. It has amino acids at $1.907 \%$ as thiamin, cysteine, glycine, histidine, isoleucine, leucine, lysine, phenylalanine, threonine, tryptophane, tyrosine, and valine. It contains vitamins at $0.038 \%$ as thiamine, biotiene, choline, folic acid, niacin, pantothenic, pyrodxine, and rhiboflavin. It contains $\mathrm{N}, \mathrm{P}\left(\mathrm{P}_{2} \mathrm{O}_{5}\right)$, and $\mathrm{K}_{2} \mathrm{O}$ at $1125,559,625 \mathrm{mg} . \mathrm{l}^{-1}$., respectively. It also contains the micro nutrients Fe 160 mg. ${ }^{-1}, \mathrm{Zn} \mathrm{124,} \mathrm{Mn} \mathrm{100,} \mathrm{Mg} \mathrm{45,} \mathrm{Cu} \mathrm{45,} \mathrm{B} \mathrm{14,} \mathrm{Mo} \mathrm{12,} \mathrm{Cd} \mathrm{7,}$ and $\mathrm{Ni} 4$ (Tamer 2018 and Hala 2009). As described, Biomagic is used as plant growth promoter. Biomagic is a readymade product that is formulated by the microbiological unit for propagating and marketing plant growth promoters at the Desert Research Center at El-Matariya, Cairo, Egypt.

Peanut (Arachis hypogaea L. cultivar Giza 6) seeds were purchased at the Agricultural assembly for producing and marketing enhanced seeds of field crops of the Ministry of Agriculture, Giza, Egypt. Seedbed was prepared by hand-hoeing to remove the weeds, then the field surface was furrowed and dripper lines were spread along the furrows. Seeding took place on March 27, 2016 in the first season, and on March 29, 2017 in the second season. On seeding day, water was dripped onto the furrows immediately prior to seeding. Using a wooden cone, two peanut seeds, treated or untreated, were sown in $30 \mathrm{~cm}$ apart hills in the furrows which were $50 \mathrm{~cm}$ apart from each other and covered with soil. Plant population was 28000 plant.feddan $^{-1}$ after thinning to one plant.hill ${ }^{-1}$ ( 1 feddan=0.42 ha).

After 45 days from seeding, total microbial count, Azotoacter density, P-dissolvers density, rhizobium sp. and the most probable number (MPN) of cellulose decomposers density were measured in the rhizosphere under peanut plants. Peanuts were harvested after 130 days from planting. The following data were recorded; Plant height, plant dry weight, nodules' dry weight plant ${ }^{-1}$, weight of seeds $(\mathrm{g})$, and seed content $(\%)$ of oil, protein, phosphorus, and potassium. Determination of the these seed contents will be referred to later on within the samples analyses.

Noteworthy is that all other field practices such as irrigation, plants thinning, weed control, pest management, and NPK fertilization were achieved the same for all treatments.

\section{Soil samples:}

Samples of soil and irrigation water were collected for analysis at the time of seedbed preparation from the $0-30 \mathrm{~cm}$ surface soil layer. Physiochemical properties of the soil and water were determined. At harvest, soil samples were collected from the same top soil layer. All 
collected soil sampled were exposed to analysis after being air-dried, crushed, sieved through a $2 \mathrm{~mm}$ sieve, and preserved for analysis.

For the initial soil samples, $\mathrm{pH}$, electrical conductivity (EC), cationic and anionic profiles, and calcium carbonate were determined according to the methods described by Richards (1954) and Jackson (1963). Particle size distribution was assessed by the pipette method of Piper (1950). The obtained data are reported in Table 1 to give an image about the initial soil situation prior to cultivation. This is not going to be traced throughout peanut life span to concentrate on the objective of the current research work.

For water samples, $\mathrm{pH}$, total salinity $(\mathrm{EC})$, major cations $\left(\mathrm{Na}^{+}, \mathrm{K}^{+}\right.$, $\left.\mathrm{Mg}^{+2}, \mathrm{Ca}^{+2}\right)$ and major anions $\left(\mathrm{Cl}^{-1}, \mathrm{SO}_{4}^{-2}, \mathrm{CO}_{3}^{-2}, \mathrm{HCO}_{3}^{-1}\right)$ were determined by ion chromatography (ICS-1100, Dionex, Sunnyvale, CA, USA). The obtained data are reported in Table 1.

Table (1): Physicochemical and Chemical analysis of initial cultivated soil, irrigation water, Olive pomace and organic compost in Baloza station.

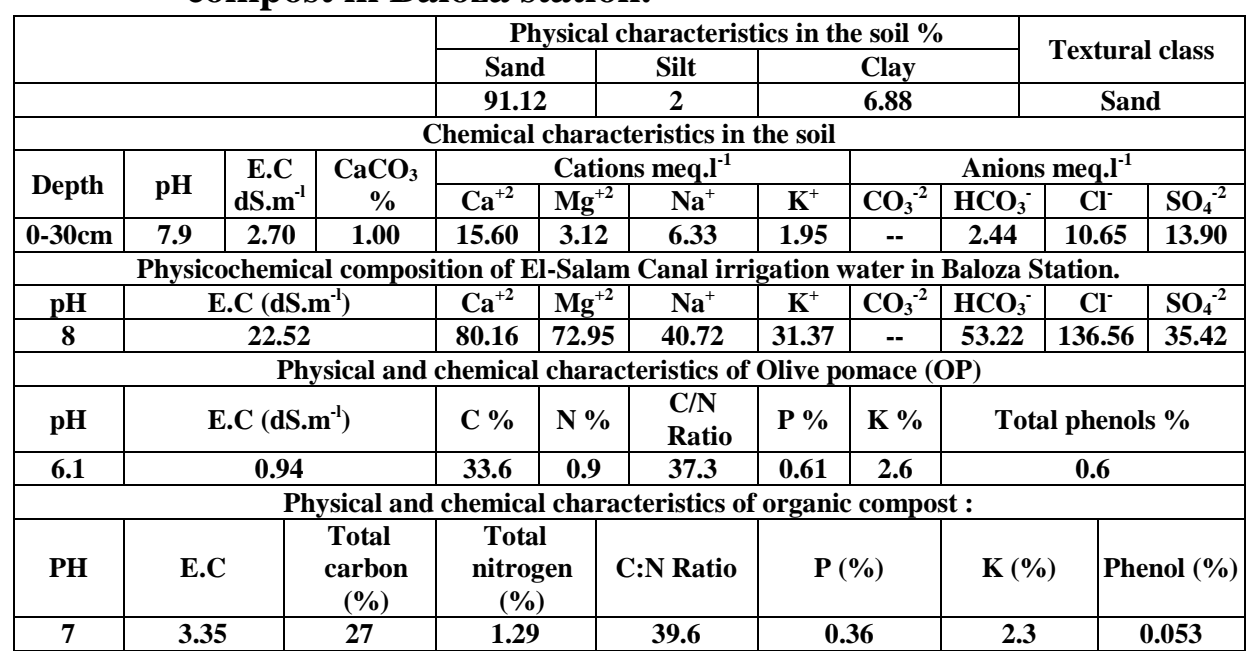

The recruited organic (olive) was composed of $60 \%$ olive pomace (OP) from an olive presses in North Sinai and $40 \%$ agricultural byproduct of rice straw, weeds and palm fronds. Olive pomace was nourished with a highly active cellulose degrading bacteria (CDB) (Pseudomonas fluorescents sub sp.). The resulting compost was sampled and analyzed. The EC and $\mathrm{pH}$ were analyzed in 1:5 (v/v) soil to water extract. Organic carbon and total nitrogen were assessed and recorded as described by Bremner and Mulvaney, (1982) and Cappuccino and Sherman (1992), respectively. Then, $\mathrm{C} / \mathrm{N}$ ratio was calculated and reported. Total phosphorus and potassium were measured as described by Watanabe and Olsen, (1965); Mason, (1963), respectively. In addition, 
total phenol content was measured using the modified method by Romero et al. (2002). The obtained data are reported in Table (1). Microbiological determinations:

Microbiological analysis of soil included the determination of total microbial counts $\left(10^{6} \mathrm{cfu} \mathrm{g}^{-1}\right.$ dry soil), phosphate dissolver counts $\left(10^{3}\right.$ cfu/g dry soil) by plating on modified Bunt and Rovira medium (AbdelHafez, 1966), Rhizobium leguminosarum, Yeast extract manitol agar (YMA) medium (Allen, 1959), densities of Azotobacter chroococcum $\left(10^{3} \mathrm{cfu}^{-1}\right.$ dry soil), Ashby's modified medium (Abdel-Malek and Ishac 1968) and Estimates of number of cellulose decomposers by MPN technique $\left(10^{3}\right.$ cells.g ${ }^{-1}$ dry soil) were calculated using Cochran's tables (Cochran, 1950).

\section{Applied treatments:}

1. Organic fertilizer, OM

1.1. Without OM, OM0

1.2. Olive processing waste $(60 \%)+$ rice straw $(40 \%)$ added to soil at the rate of $5 \mathrm{mt} /$ feddan, OM1.

2. Foliar nutrition, M

2.1. Control without foliar spraying, M0.

2.2. Foliar spraying with a readymade product Biomagic, M1.

3. Bio-fertilizer, I

3.1. Control treated with Rhizobium sp. only, I Rhizo.

3.2. Inoculated with Azotoacter sp, I Azoto.

3.3. Inoculated with phosphorous dissolving bacteria Bacillus megaterium, I PDB.

3.4. Mixed (Inoculated with Azotoacter sp. and Bacillus megaterum), I mix

Statistical analysis:

The factorial combinations among the three major treatments were arranged in the experimental field in a factorial design in three replicates. According to the general linear model (GLM) of the linear algebra, the mathematical model resembling the sources of variance affecting the measured traits of peanut will be followed. This model tells that the effects of the applied treatments will be exposed and discussed under the following sources, namely the influence of organic compost (OM), Biomagic (M), inoculation (I), OM x M, OM x I, M x I, and OM x M x I interaction. Therefore, the tabulated data will be under these seven sources of variance. To verdict among the various mean values for the effects of the applied treatments will be based on the Duncan least significant range (LSR) at 5\% level of significance. All mean values will be denoted with alphabetical letters. In other words, every two mean values sharing an alphabet are to be considered as being not significantly different. 


\section{RESULTS AND DISCUSSION}

\section{Effects of applied treatments on soil microbiological counts and densities:}

Data depicted in Table 2 show that the application of OM (compost) significantly enhance the biological population in the rhizosphere under peanut plants in both years of study compared to no application. This can directly reasoned by that compost resembles a basic substrate for all microorganisms. This finding coincides with that found by Dharma (1996) who stated that FYM stimulated the activities of microorganisms that render plant nutrients available to crops.

In Table 2, spraying Biomagic was steadily better than non-spraying in proliferating the highest significant total bacterial count, density of Azotobacter, density of P-dissolvers, Rhizobium sp., and MPN cellulose decomposers in both years of study. This can be related to the effect of Biomagic escaping the plant canopy and reaching the soil solution and being available to microorganisms and plant roots. This finding is supported by Tamer (2018). He stated that Biomagic is a microbial bioactive non hormonal foliar spray. It has amino acids, vitamins, macronutrients $\mathrm{N}, \mathrm{P}, \mathrm{K}$, $\mathrm{Mg}$, and micronutrients. Biomagic can be sprayed on plants to promote their growth.

It can be seen that the mixed inoculation with Azotobter and PDB significantly proliferate better growth conditions in the rhizosphere to the microbial population in both years of study.

Mixed inoculation was significantly better, in this regard, than inoculation with Azotobacter alone was significantly better than inoculation with PDB alone. Mixed or separate inoculation with Azotobter and PDB significantly surpassed the control treatment which was inoculated with Rhizobium only. It can be stated that the following descending rank can effectively describe the situation among the four biological inoculation treatments: mixed > Azotobacter > PDB > control (inoculated with Rhizobium. Also, it can be concluded that mixed inoculation significantly lifted the influence of rhizobium inoculation for the nourishment of biological population in the rhizosphere under peanut plants. This observation virtually means more potential toward plant feeding with more nutrients for a better growth. These findings go firmly with those stated by El- Boraie et al. (2009) and Gharib et al. (2009) who found that the highest significant pod yield was obtained from inoculating the seeds with a mixture of Rhizobium + Azotobacter chroococcum + Bacillus megaterium.

With respect to the OM x I interaction, the application of compost and spraying the plants with Biomagic could have its significant fingerprints on the activation of biological population in the rhizosphere in both years of study. 
Table 2. Influence of the applied treatments on counts of total bacterial, Azotobacter, P-dissolvers, Rhizobium, and MPN of cellulose decomposers in 2015 and 2016 at Balouza, North Sinai - Egypt.

\begin{tabular}{|c|c|c|c|c|c|c|c|c|c|c|c|c|}
\hline \multirow{2}{*}{\multicolumn{2}{|c|}{ Variables }} & \multirow[t]{2}{*}{ Treatment } & \multicolumn{2}{|c|}{$\begin{array}{c}\text { Total count } \\
\left(1^{6} \text { cfu.g }^{-1} \mathrm{dry}\right. \\
\text { soil })\end{array}$} & \multicolumn{2}{|c|}{$\begin{array}{c}\text { Densities of } \\
\text { Azotobacter } \\
\left(10^{3} \text { cfu.g }^{-1} \text { dry }\right. \\
\text { soil })\end{array}$} & \multicolumn{2}{|c|}{$\begin{array}{c}\text { Densities of } \\
\text { P-dissolvers } \\
\left(\mathbf{1 0}^{3} \text { cfu.g }^{-1} \text { dry }\right. \\
\text { soil })\end{array}$} & \multicolumn{2}{|c|}{$\begin{array}{l}\text { Rhizobium } \\
\text { spp x10 }\end{array}$} & \multicolumn{2}{|c|}{$\begin{array}{c}\text { MPN of cellulose } \\
\text { decomposers } \\
\left(10^{3} \text { cells.g }{ }^{-1} \text { dry }\right. \\
\text { soil })\end{array}$} \\
\hline & & & 2015 & 2016 & 2015 & 2016 & 2015 & 2016 & 2015 & 2016 & 2015 & 2016 \\
\hline \multirow{2}{*}{\multicolumn{2}{|c|}{ OM }} & $\mathbf{0}$ & $82 \mathrm{~b}$ & $90 \mathrm{~b}$ & $\overline{100 ~ b}$ & $\overline{105 ~ b}$ & $88 \mathrm{~b}$ & $93 \mathrm{~b}$ & $1.81 \mathrm{~b}$ & $2.13 \mathrm{~b}$ & $0.87 \mathrm{~b}$ & $0.93 \mathrm{~b}$ \\
\hline & & 1 & 105 a & 113 a & 128 a & 133 a & 119 a & 129 a & 3.19 a & $3.61 \mathrm{a}$ & $1.20 \mathrm{a}$ & $1.30 \mathrm{a}$ \\
\hline \multirow{2}{*}{\multicolumn{2}{|c|}{ M }} & 0 & $80 \mathrm{~b}$ & 89 b & $97 \mathrm{~b}$ & $101 \mathrm{~b}$ & 87 b & $95 \mathrm{~b}$ & $2.23 \mathrm{~b}$ & $2.56 \mathrm{~b}$ & $0.94 \mathrm{~b}$ & $1.00 \mathrm{~b}$ \\
\hline & & 1 & 107 a & $114 \mathrm{a}$ & 131 a & 137 a & $119 a$ & 127 a & $2.77 \mathrm{a}$ & $3.14 \mathrm{a}$ & $1.12 \mathrm{a}$ & $1.22 \mathrm{a}$ \\
\hline \multirow{4}{*}{\multicolumn{2}{|c|}{ I }} & Rhizo. & $78 \mathrm{~d}$ & $84 d$ & $81 \mathrm{~d}$ & $85 d$ & $71 \mathrm{~d}$ & $77 \mathrm{~d}$ & $1.05 \mathrm{~d}$ & $1.36 \mathrm{~d}$ & $0.82 \mathrm{~d}$ & $0.91 \mathrm{~d}$ \\
\hline & & Azto. & $95 \mathrm{~b}$ & $102 \mathrm{~b}$ & $119 \mathrm{~b}$ & $126 \mathrm{~b}$ & $104 \mathrm{~b}$ & $114 \mathrm{~b}$ & $2.95 \mathrm{~b}$ & $3.35 \mathrm{~b}$ & $1.06 \mathrm{~b}$ & $1.14 \mathrm{~b}$ \\
\hline & & PDB & $88 \mathrm{c}$ & $95 \mathrm{c}$ & $112 \mathrm{c}$ & $117 \mathrm{c}$ & $101 \mathrm{c}$ & $110 \mathrm{c}$ & $2.67 \mathrm{c}$ & $2.95 \mathrm{c}$ & $1.00 \mathrm{c}$ & $1.07 \mathrm{c}$ \\
\hline & & Mix & 115 a & 126 a & $144 a$ & 149 a & 134 a & 143 a & $3.34 \mathrm{a}$ & 3.81 a & $1.25 \mathrm{a}$ & $1.33 \mathrm{a}$ \\
\hline \multirow{4}{*}{\multicolumn{2}{|c|}{ OMxM }} & 0x0 & $67 d$ & $76 \mathrm{c}$ & $87 d$ & $92 \mathrm{~d}$ & $75 \mathrm{c}$ & $81 \mathrm{c}$ & $1.64 \mathrm{~d}$ & $1.89 \mathrm{~d}$ & $0.81 \mathrm{~d}$ & $0.88 \mathrm{~d}$ \\
\hline & & 0x1 & $97 \mathrm{~b}$ & $104 \mathrm{~b}$ & $113 \mathrm{~b}$ & $118 \mathrm{~b}$ & $99 \mathrm{~b}$ & $105 \mathrm{~b}$ & $1.98 \mathrm{c}$ & $2.37 \mathrm{c}$ & $0.92 \mathrm{c}$ & $0.97 \mathrm{c}$ \\
\hline & & 1x0 & $94 \mathrm{c}$ & $\overline{103 ~ b}$ & $106 \mathrm{c}$ & $110 \mathrm{c}$ & $99 \mathrm{~b}$ & $109 \mathrm{~b}$ & $2.83 \mathrm{~b}$ & $\mathbf{0 b}$ & $1.07 \mathrm{~b}$ & $1.12 \mathrm{~b}$ \\
\hline & & 1x1 & 118 a & 124 a & 149 a & 156 a & 138 a & 149 a & $3.56 \mathrm{a}$ & $2 a$ & $1.33 \mathrm{a}$ & $1.47 \mathrm{a}$ \\
\hline \multirow{8}{*}{\multicolumn{2}{|c|}{ OMxI }} & 0xRh & $67 \mathrm{f}$ & $73 \mathrm{f}$ & $74 \mathrm{~g}$ & $79 \mathrm{~g}$ & $61 \mathrm{f}$ & $68 \mathrm{~g}$ & $0.21 \mathrm{~h}$ & $0.37 \mathrm{~g}$ & $0.733 \mathrm{e}$ & $0.80 \mathrm{f}$ \\
\hline & & 0xAzo. & $83 \mathrm{~d}$ & $91 \mathrm{~d}$ & $103 d$ & $110 \mathrm{~d}$ & $87 \mathrm{~d}$ & $92 \mathrm{e}$ & $2.34 \mathrm{e}$ & $2.73 \mathrm{e}$ & $\begin{array}{l}0.90 \mathrm{~cd} \\
\end{array}$ & $0.96 \mathrm{de}$ \\
\hline & & 0xPDB & $76 \mathrm{e}$ & 83 e & $97 \mathrm{e}$ & 102 e & 84 de & $89 \mathrm{f}$ & $2.11 \mathrm{f}$ & $2.29 \mathrm{f}$ & $0.86 \mathrm{~d}$ & 0.90 ef \\
\hline & & 0xMix & 103 bc & $114 \mathrm{~b}$ & $127 \mathrm{c}$ & $131 \mathrm{c}$ & $115 \mathrm{c}$ & $121 \mathrm{~d}$ & $2.58 \mathrm{~d}$ & $3.12 \mathrm{~d}$ & $0.98 \mathrm{c}$ & $1.04 \mathrm{~d}$ \\
\hline & & 1xRh. & $89 d$ & $94 d$ & $88 \mathrm{f}$ & $90 \mathrm{f}$ & $82 \mathrm{e}$ & $86 \mathrm{f}$ & $1.88 \mathrm{~g}$ & $2.35 \mathrm{f}$ & $0.92 \mathrm{~cd}$ & $1.01 \mathrm{~d}$ \\
\hline & & 1xAzo. & $106 \mathrm{~b}$ & $114 \mathrm{~b}$ & $134 \mathrm{~b}$ & 142 b & $122 \mathrm{~b}$ & $135 \mathrm{~b}$ & $3.55 \mathrm{~b}$ & $3.98 \mathrm{~b}$ & $1.22 \mathrm{~b}$ & $1.31 \mathrm{~b}$ \\
\hline & & 1XPDB & $99 \mathrm{c}$ & $107 \mathrm{c}$ & $128 \mathrm{c}$ & $133 \mathrm{c}$ & $118 \mathrm{c}$ & $130 \mathrm{c}$ & $3.23 \mathrm{c}$ & $3.62 \mathrm{c}$ & $1.14 b$ & $1.25 \mathrm{c}$ \\
\hline & & 1xMix & 127 a & 139 a & 160 a & 168 a & 154 a & $164 a$ & $4.10 \mathrm{a}$ & 4.5 & $1.52 \mathrm{a}$ & $1.62 \mathrm{a}$ \\
\hline \multirow{8}{*}{\multicolumn{2}{|c|}{ M $\mathbf{x} \mathbf{I}$}} & Rh. & $70 \mathrm{~g}$ & $76 \mathrm{f}$ & $70 \mathrm{~h}$ & $74 \mathrm{~h}$ & $63 \mathrm{f}$ & $69 \mathrm{~h}$ & $0.82 \mathrm{~h}$ & $2 g$ & $0.79 \mathrm{~g}$ & $0.85 \mathrm{~g}$ \\
\hline & & 0xAzo. & $80 \mathrm{f}$ & $90 \mathrm{~d}$ & 102 e & 107 e & $89 \mathrm{~d}$ & 99 e & $2.65 \mathrm{e}$ & $3.11 \mathrm{~d}$ & $0.97 \mathrm{e}$ & $1.04 \mathrm{e}$ \\
\hline & & 0XPDB & $76 \mathrm{f}$ & $84 \mathrm{e}$ & $95 \mathrm{f}$ & $101 \mathrm{f}$ & $86 \mathrm{~d}$ & $95 \mathrm{f}$ & $2.50 \mathrm{f}$ & $2.78 \mathrm{e}$ & $0.93 \mathrm{e}$ & $0.96 \mathrm{f}$ \\
\hline & & 0xMix & $96 \mathrm{~d}$ & $107 \mathrm{c}$ & $120 \mathrm{~d}$ & $124 \mathrm{~d}$ & $111 \mathrm{c}$ & $117 d$ & $2.96 \mathrm{c}$ & $3.48 \mathrm{c}$ & $1.07 \mathrm{c}$ & $1.15 \mathrm{~d}$ \\
\hline & & 1xRh. & 87 e & $92 d$ & $91 \mathrm{~g}$ & $96 \mathrm{~g}$ & 80 e & $85 \mathrm{~g}$ & $1.28 \mathrm{~g}$ & $1.70 \mathrm{f}$ & $0.86 \mathrm{f}$ & $0.96 \mathrm{f}$ \\
\hline & & 1xAzo. & $110 \mathrm{~b}$ & $115 \mathrm{~b}$ & $136 \mathrm{~b}$ & $145 \mathrm{~b}$ & $120 \mathrm{~b}$ & $128 \mathrm{~b}$ & $3.24 \mathrm{~b}$ & $3.59 \mathrm{~b}$ & $1.15 \mathrm{~b}$ & $1.24 \mathrm{~b}$ \\
\hline & & 1Xpdb & $100 \mathrm{c}$ & & $129 \mathrm{c}$ & $134 \mathrm{c}$ & $117 \mathrm{~b}$ & $125 \mathrm{c}$ & $2.84 \mathrm{~d}$ & 3.13 d & $1.07 \mathrm{~d}$ & $1.19 \mathrm{c}$ \\
\hline & & 1xMix & 134 a & 145 a & 167 a & 175 a & 158 a & 168 a & $3.72 \mathrm{a}$ & $4.14 \mathrm{a}$ & $1.42 \mathrm{a}$ & $1.51 \mathrm{a}$ \\
\hline \multirow{8}{*}{ OM0 } & \multirow{4}{*}{ M0 } & Rhiz. & 581 & $64 j$ & $61 \mathrm{j}$ & $65 \mathrm{~m}$ & $51 \mathrm{k}$ & $58 \mathrm{~m}$ & $0.06 \mathrm{~m}$ & $0.11 \mathrm{n}$ & $0.68 \mathbf{j}$ & 0.760 \\
\hline & & Azto. & $63 \mathrm{k1}$ & $73 \mathrm{i}$ & 95 gh & $101 \mathrm{i}$ & $80 \mathrm{~h}$ & $87 \mathbf{j}$ & $2.08 \mathrm{j}$ & $8 \mathrm{j}$ & 0.85gh & 0.921 \\
\hline & & PDB & $61 \mathrm{kl}$ & & $91 \mathrm{~h}$ & $96 \mathbf{j k}$ & 77 hi & $82 \mathrm{k}$ & 2.0 & $2 \mathrm{k}$ & 0.81 hi & $0.86 \mathrm{~m}$ \\
\hline & & & $87 \mathrm{~h}$ & $97 \mathrm{f}$ & $103 \mathrm{f}$ & $107 \mathrm{~h}$ & $90 \mathrm{~g}$ & $96 \mathrm{~h}$ & $2.40 \mathrm{~h}$ & $2.93 \mathrm{~g}$ & 0.91 ef & $0.97 \mathbf{j}$ \\
\hline & \multirow{4}{*}{ M1 } & Rhiz. & $75 \mathrm{j}$ & $82 \mathrm{~h}$ & $86 i$ & $93 \mathrm{k}$ & $71 \mathrm{j}$ & 781 & 0.37 I & $0.63 \mathrm{~m}$ & $0.77 \mathrm{i}$ & $0.84 \mathrm{n}$ \\
\hline & & Azto. & $103 \mathrm{e}$ & $109 d$ & $112 \mathrm{e}$ & $119 \mathrm{f}$ & 94 ef & $98 \mathrm{~h}$ & $2.60 \mathrm{~g}$ & $2.97 \mathrm{~g}$ & $0.95 \mathrm{e}$ & $1.00 \mathrm{i}$ \\
\hline & & PDB & $91 \mathrm{~g}$ & $95 \mathrm{f}$ & $102 \mathrm{f}$ & $107 \mathrm{~h}$ & $91 \mathrm{fg}$ & 95 hi & $2.20 \mathrm{i}$ & $2.57 \mathrm{i}$ & 0.92 ef & $0.94 \mathrm{k}$ \\
\hline & & & $119 \mathrm{~b}$ & $131 \mathrm{~b}$ & $151 \mathrm{c}$ & $155 d$ & $139 \mathrm{c}$ & $147 d$ & $2.75 \mathrm{f}$ & $3.30 \mathrm{f}$ & $1.05 \mathrm{~d}$ & $1.10 \mathrm{f}$ \\
\hline \multirow{8}{*}{ OM1 } & \multirow{4}{*}{ M0 } & & 81 i & $87 \mathrm{~g}$ & 79 i & 821 & $75 \mathrm{i}$ & $80 \mathrm{kl}$ & $1.58 \mathrm{k}$ & 1.93 I & $0.89 \mathrm{fg}$ & $0.94 \mathrm{k}$ \\
\hline & & & $97 \mathrm{f}$ & $107 d$ & 109 e & $112 \mathrm{~g}$ & $97 \mathrm{e}$ & $111 \mathrm{f}$ & $3.22 \mathrm{~d}$ & $3.73 \mathrm{~d}$ & $1.09 \mathrm{~d}$ & $1.15 \mathrm{e}$ \\
\hline & & PDB & $90 \mathrm{~g}$ & & $99 \mathrm{fg}$ & $6 \mathrm{~h}$ & 94 ef & $107 \mathrm{~g}$ & $2.98 \mathrm{e}$ & $3.53 \mathrm{e}$ & $1.05 \mathrm{~d}$ & $1.06 \mathrm{~h}$ \\
\hline & & & 106 de & $118 \mathrm{c}$ & $138 \mathrm{~d}$ & $141 \mathrm{e}$ & $131 \mathrm{~d}$ & $138 \mathrm{e}$ & $3.52 \mathrm{c}$ & $4.02 \mathrm{c}$ & $1.24 \mathrm{c}$ & $1.33 \mathrm{~d}$ \\
\hline & \multirow{4}{*}{ M1 } & Rhiz. & $98 \mathrm{f}$ & 101 e & $96 \mathrm{~g}$ & $99 \mathbf{i j}$ & $89 \mathrm{~g}$ & $92 \mathbf{i}$ & $2.18 \mathrm{i}$ & $2.77 \mathrm{~h}$ & $0.95 \mathrm{e}$ & $1.08 \mathrm{~g}$ \\
\hline & & Azto. & $116 \mathrm{c}$ & $120 \mathrm{c}$ & $160 \mathrm{~b}$ & $171 \mathrm{~b}$ & $146 \mathrm{~b}$ & $159 \mathrm{~b}$ & $\mathbf{3 . 8 8} \mathrm{b}$ & $4.22 \mathrm{~b}$ & $1.34 \mathrm{~b}$ & $1.47 \mathrm{~b}$ \\
\hline & & PDB & $108 \mathrm{~d}$ & $117 \mathrm{c}$ & $157 \mathrm{~b}$ & $160 \mathrm{c}$ & $142 \mathrm{c}$ & $154 \mathrm{c}$ & $3.48 \mathrm{c}$ & $3.70 \mathrm{~d}$ & $1.23 \mathrm{c}$ & $1.43 \mathrm{c}$ \\
\hline & & Mix & 148 a & 159 a & 183 a & 195 a & $177 \mathrm{a}$ & $190 \mathrm{a}$ & $4.68 \mathrm{a}$ & $4.98 \mathrm{a}$ & $1.79 \mathrm{a}$ & $1.91 \mathrm{a}$ \\
\hline
\end{tabular}

Data also reveal that spraying Biomagic without compost had no significant difference from applying compost without spraying with Biomagic in the second year on total bacterial count, while in both years on the density of PDB. For the other counts in Table 2, spraying with Biomagic alone significantly surpassed the application of compost alone. Normally, 
the least effective situation on biological growth in the rhizosphere can be seen with 0 compost and 0 Biomagic.

These findings go well with those reported by El-Fouly and El-Sayed (1997) who reported that foliar feeding of a nutrient promoted root absorption of the same nutrient or other nutrients through improving root growth and increasing nutrients uptake.

In addition, El- Boraie et al. (2009) recommended the daily application of irrigation water and inoculation with a mixture of Rhizobium + Azotobacter chroococcum + Bacillus megaterium to achieve the highest significant peanut pod yield. This implies that the application of Biomagic to the soil via fertigation in the form of short spurs from drip irrigation system; i.e. daily application will have to be beneficial to peanut seed production. Such mode of application is expected to give the roots greater chance to absorb nutrients avoiding the nutrients' losses that take place with the bulky application of irrigation water.

Regarding the $\mathrm{OM} \times \mathrm{I}$ interaction, Table 2 exhibits that the performance of the four biological treatments with organic compost was superior to without it for all measured biological traits; bacterial densities or counts. The best combination treatment is composed of applying compost and inoculating with a mixture of Azotobacter and PDB. This finding holds true for both years of study. It coincides with the finding of Balasubramanian and Palaniappan (1994) who reported that the use of microbial inoculants in combination with FYM favored groundnut production. This finding parallels that found by Dharma (1996) who stated that FYM stimulated the activities of microorganisms and rendered plant nutrients available to crops' roots.

Concerning the M x I interaction, Table 2 tells that the performance of biofertilizers treatments with Biomagic was prominent to that without it in both years of study. The best combination treatment was that composed of inoculating peanut plants with a mixture of Azotobacter and PDB with spraying the plants with Biomagic. In support to this finding, El-Fouly and El-Sayed (1997) stated that foliar feeding of a nutrient promoted root absorption of the same nutrient or other nutrients through improving root growth and increasing nutrients uptake. In addition, Abou-El-Nour (2002) concluded that supplying $\mathrm{N}$ either from foliar sources or symbiotic fixation resulted in greater nitrogen content in the leaf canopy and increased biomass production.

For the 3-factor interaction (OM x M x I), Table 2 shows that the superior treatment was that composed of applying compost + spraying with Biomagic + mixed inoculation with Azotobacter and PDB. This was true in both years of study for all measure biological counts and densities. This finding comes true with that by Gharib et al. (2009) who stated that mixed $(\mathrm{Rh}+\mathrm{AZ}+\mathrm{BM})$ treatments in the presence of $25 \%$ of the recommended 
dose of chemical NPK fertilizers had highly significant effects on snap been growth, nodulation, and $\mathrm{N}_{2}$-fixation. In support, Tamer (2018) reported that Biomagic is a microbial bioactive non hormonal foliar spray which is eligible for being sprayed on plants to promote their growth. In other words, it is nutritive to microorganisms when it reaches soil solution.

Effects of applied treatments on plant height, dry weight, and nodule dry weight:

Data enclosed in Table 3 reveal that the scenarios of effects shown in Table 2 and discussed popped up approximately the same in Table 3. In that, the application of compost could significantly surpass no application in producing the highest plant height, plant dry weight, and nodules dry weight. This held true for both years of study. These findings are supported by those of Dharma (1996) who found that FYM stimulated the activities of microorganisms that render plant nutrients available to crops.

Also, Ahmed et al. (1997) stated that the highest dry matter accumulation, kernel yield and oil content were achieved by fertilization with farmyard manure. Ismail $\boldsymbol{e t}$ al. (1998) reported that FYM application increased peanut dry matter production. In addition, Subrahmaniyan et al. (2000) stated that application of FYM increased pod and seed yields and improved groundnut yield parameters as shelling percentage and 100 seed weight. Also, Chandrasekaran et al. (2007) found that application of FYM produced the highest DMP. Also, Veeramani et al. (2012) reported that OMs effectively contribute to plant growth.

Biomagic application significantly enhanced peanut plant height, dry matter production, and nodules formation (Table 3) as compared with no application. This is supported by the findings of El-Fouly and El-Sayed (1997) who stated that foliar feeding promoted and increased biomass production.

Table 3 tells that mixed inoculation with Azotobacter and PDB proved to be significantly $>$ Azotobacter alone $>$ PDB alone $>$ the control that was treated with Rhizobium in both years of study in peanut plant height, plant dry matter production, and nodules dry weight. El- Boraie et al. (2009) and Gharib et al. (2009) who found that the highest significant pod yield was obtained from inoculating the seeds with a mixture of Rhizobium + Azotobacter chroococcum + Bacillus megaterium.

Viewing the mean values for the organic $\mathrm{x}$ Biomagic interaction in Table 3 reveals that applying compost and spraying the plants with Biomagic could surpass applying organic alone or spraying with Biomagic alone. This can be supported by the finding of Hanan et al. (2015) who found that the application of compost increased weight of peanut seeds and pods yields, but they recommended soil application to foliar application. This recommendation drew the attention toward the probable escape of Biomagic reaching the soil solution and contributing to the biological 
activities in the rhizosphere. In addition, foliar feeding of a nutrient promoted root absorption of the same nutrient or other nutrients through improving root growth and increasing nutrients uptake and plant growth in general (El-Fouly and El-Sayed, 1997). However, Tamer (2018) recommended foliar application to soil application reasoning by that Biomagic is a readymade product that can be sprayed on plants to promote their growth.

Table 3. Influence of the applied treatments on plant height, plant dry weight, and nodules dry weight plant $^{-1}$ in 2015 and 2016 at Balouza, North Sinai - Egypt.

\begin{tabular}{|c|c|c|c|c|c|c|c|c|}
\hline \multirow{2}{*}{\multicolumn{2}{|c|}{ Variables }} & \multirow{2}{*}{$\underset{\text { nt }}{\text { Treatme }}$} & \multicolumn{2}{|c|}{ Plant height (cm) } & \multicolumn{2}{|c|}{ Plant dry weight (g) } & \multicolumn{2}{|c|}{$\begin{array}{c}\text { Nodules dry } \\
\text { weight.plant }^{-1}(\mathrm{~g})\end{array}$} \\
\hline & & & 2015 & 2016 & 2015 & 2016 & 2015 & 2016 \\
\hline \multirow{2}{*}{\multicolumn{2}{|c|}{ OM }} & $\mathbf{0}$ & $28 \mathrm{~b}$ & $34 \mathrm{~b}$ & $47 \mathrm{~b}$ & $60 \mathrm{~b}$ & $0.19 \mathrm{~b}$ & $0.25 \mathrm{~b}$ \\
\hline & & 1 & 48 a & 54 a & $92 \mathbf{a}$ & 113 a & $0.65 \mathrm{a}$ & $0.71 \mathrm{a}$ \\
\hline \multirow{2}{*}{\multicolumn{2}{|c|}{ M }} & $\mathbf{0}$ & $34 \mathrm{~b}$ & $38 \mathrm{~b}$ & $57 \mathrm{~b}$ & $73 \mathrm{~b}$ & 0.31 b & 0.37 b \\
\hline & & 1 & $42 \mathbf{a}$ & 49 a & $82 \mathbf{a}$ & $99 \mathbf{a}$ & $0.53 \mathrm{a}$ & 0.59 a \\
\hline \multirow{4}{*}{\multicolumn{2}{|c|}{ I }} & Rhizo. & $26 \mathrm{~d}$ & $33 \mathrm{~d}$ & $50 \mathrm{~d}$ & $62 d$ & $0.23 \mathrm{~d}$ & $0.28 \mathrm{~d}$ \\
\hline & & Azto. & $41 \mathrm{~b}$ & $47 \mathrm{~b}$ & $75 \mathrm{~b}$ & $90 \mathrm{~b}$ & $0.45 \mathrm{~b}$ & $0.50 \mathrm{~b}$ \\
\hline & & PDB & $37 \mathrm{c}$ & $41 \mathrm{c}$ & $65 \mathrm{c}$ & $77 \mathrm{c}$ & $0.38 \mathrm{c}$ & $0.46 \mathrm{c}$ \\
\hline & & Mix & 48 a & 54 a & 89 a & $116 \mathbf{a}$ & $0.63 \mathrm{a}$ & 0.69 a \\
\hline \multirow{4}{*}{\multicolumn{2}{|c|}{ OMxM }} & 0x0 & $25 \mathrm{~d}$ & $29 \mathrm{~d}$ & $39 \mathrm{~d}$ & $50 \mathrm{~d}$ & $0.11 \mathrm{~d}$ & $0.19 \mathrm{~d}$ \\
\hline & & 0x1 & $32 \mathrm{c}$ & $39 \mathrm{c}$ & $55 \mathrm{c}$ & $69 \mathrm{c}$ & $0.27 \mathrm{c}$ & $0.32 \mathrm{c}$ \\
\hline & & $\mathbf{1 x 0}$ & $44 \mathrm{~b}$ & $47 \mathrm{~b}$ & $75 \mathrm{~b}$ & $98 \mathrm{~b}$ & 0.51 b & $0.56 \mathrm{~b}$ \\
\hline & & 1x1 & 52 a & $60 \mathrm{a}$ & 110 a & 129 a & $0.80 \mathrm{a}$ & 0.87 a \\
\hline \multirow{8}{*}{\multicolumn{2}{|c|}{ OMxI }} & OxRh & $21 \mathrm{~g}$ & $25 \mathrm{~h}$ & $35 \mathrm{~h}$ & $45 \mathrm{~h}$ & $0.12 \mathrm{~h}$ & $0.16 \mathrm{~g}$ \\
\hline & & 0xAzo. & 29 ef & $37 \mathrm{f}$ & $50 \mathrm{f}$ & $61 \mathrm{f}$ & $0.20 \mathrm{f}$ & $0.23 \mathrm{f}$ \\
\hline & & 0xPDB & $27 \mathrm{f}$ & $30 \mathrm{~g}$ & $\overline{41 \mathrm{~g}}$ & $54 \mathrm{~g}$ & $0.14 \mathrm{~g}$ & $0.25 \mathrm{f}$ \\
\hline & & 0xMix & $37 \mathrm{~d}$ & $43 d$ & $62 \mathrm{e}$ & $78 \mathrm{~d}$ & $0.29 \mathrm{e}$ & $0.37 \mathrm{e}$ \\
\hline & & 1xRh. & $31 \mathrm{e}$ & $41 \mathrm{e}$ & $65 d$ & $80 \mathrm{~d}$ & $0.33 \mathrm{~d}$ & $0.40 \mathrm{~d}$ \\
\hline & & $1 \times$ Azo. & $53 \mathrm{~b}$ & $56 \mathrm{~b}$ & $99 \mathrm{~b}$ & $120 \mathrm{~b}$ & $0.70 \mathrm{~b}$ & $0.77 \mathrm{~b}$ \\
\hline & & 1XPDB & $47 c$ & $52 \mathrm{c}$ & $89 \mathrm{c}$ & $101 \mathrm{c}$ & $0.62 \mathrm{c}$ & $0.67 \mathrm{c}$ \\
\hline & & 1xMix & $61 \mathrm{a}$ & $65 a$ & 116 a & 154 a & 0.97 a & $1.02 \mathrm{a}$ \\
\hline \multirow{8}{*}{\multicolumn{2}{|c|}{$\mathbf{M} \times \mathbf{I}$}} & 0xRh. & $23 \mathrm{~g}$ & $30 \mathrm{~g}$ & $44 \mathrm{~h}$ & $54 \mathrm{~h}$ & $0.17 \mathrm{f}$ & $0.20 \mathrm{~g}$ \\
\hline & & 0xAzo. & $37 \mathrm{~d}$ & $40 \mathrm{~d}$ & $61 \mathrm{e}$ & $78 \mathrm{e}$ & $0.31 \mathrm{~d}$ & $0.35 \mathrm{f}$ \\
\hline & & 0XPDB & $33 \mathrm{e}$ & $35 \mathrm{f}$ & $51 \mathrm{~g}$ & $64 \mathrm{~g}$ & $0.27 \mathrm{e}$ & $0.38 \mathrm{e}$ \\
\hline & & 0xMix & $45 \mathrm{~b}$ & $48 \mathrm{c}$ & $72 d$ & $99 \mathrm{c}$ & $0.47 \mathrm{c}$ & $0.57 \mathrm{c}$ \\
\hline & & 1xRh. & $29 \mathrm{f}$ & 37 ef & $56 \mathrm{f}$ & $71 \mathrm{f}$ & $0.28 \mathrm{e}$ & 0.37 ef \\
\hline & & $1 \times A z o$. & $45 \mathrm{~b}$ & $53 \mathrm{~b}$ & 89 b & $103 \mathrm{~b}$ & $0.59 \mathrm{~b}$ & $0.65 \mathrm{~b}$ \\
\hline & & 1Xpdb & $41 \mathrm{c}$ & $47 \mathrm{c}$ & $79 \mathrm{c}$ & $91 \mathrm{~d}$ & $0.48 \mathrm{c}$ & $0.54 \mathrm{~d}$ \\
\hline & & 1xMix & 54 a & $61 \mathrm{a}$ & 106 a & 133 a & $0.78 \mathrm{a}$ & $0.82 \mathrm{a}$ \\
\hline \multirow{8}{*}{ OM0 } & \multirow{4}{*}{ M0d } & Rhiz. & $19 \mathbf{j}$ & $23 \mathbf{j}$ & $31 \mathrm{n}$ & $41 \mathrm{k}$ & $0.05 \mathrm{i}$ & $0.06 \mathbf{j}$ \\
\hline & & Azto. & $25 \mathrm{gh}$ & $30 \mathrm{~h}$ & $40 \mathrm{l}$ & $51 \mathbf{j}$ & 0.09 i & $0.10 \mathbf{j}$ \\
\hline & & PDB & $22 \mathrm{i}$ & $25 \mathrm{ij}$ & $34 \mathrm{~m}$ & $43 k$ & $0.08 \mathrm{i}$ & $0.26 \mathrm{i}$ \\
\hline & & Mix & $32 \mathrm{f}$ & $38 \mathrm{f}$ & $51 \mathbf{j}$ & $63 \mathrm{i}$ & $0.21 \mathrm{~h}$ & $0.33 \mathrm{~h}$ \\
\hline & \multirow{4}{*}{ M1 } & Rhiz. & $23 \mathrm{hi}$ & $27 i$ & 391 & $49 \mathrm{j}$ & $0.20 \mathrm{~h}$ & $0.27 \mathrm{i}$ \\
\hline & & Azto. & 33 ef & $44 \mathrm{e}$ & $60 \mathrm{~h}$ & $72 \mathrm{~g}$ & $0.30 \mathrm{~g}$ & 0.37 gh \\
\hline & & PDB & $31 \mathrm{f}$ & $34 \mathrm{~g}$ & $48 \mathrm{k}$ & 65 hi & $0.20 \mathrm{~h}$ & 0.23 i \\
\hline & & Mix & $42 d$ & $49 d$ & $73 \mathrm{f}$ & $92 \mathrm{e}$ & $0.37 \mathrm{f}$ & $0.40 \mathrm{~g}$ \\
\hline \multirow{8}{*}{ OM1 } & \multirow{4}{*}{ M0 } & Rhiz. & $27 \mathrm{~g}$ & $36 \mathrm{fg}$ & $57 \mathrm{i}$ & $67 \mathrm{~h}$ & $0.30 \mathrm{~g}$ & $0.33 \mathrm{~h}$ \\
\hline & & Azto. & $48 \mathrm{c}$ & $49 \mathrm{~d}$ & $81 \mathrm{e}$ & $105 \mathrm{~d}$ & $0.53 \mathrm{~d}$ & $0.60 \mathrm{e}$ \\
\hline & & PDB & $44 d$ & $45 \mathrm{e}$ & $68 \mathrm{~g}$ & $84 \mathrm{f}$ & $0.47 \mathrm{e}$ & $0.50 \mathrm{f}$ \\
\hline & & Mix & $55 \mathrm{~b}$ & $57 \mathrm{c}$ & $94 \mathrm{~d}$ & $134 \mathrm{~b}$ & $0.73 \mathrm{c}$ & $0.80 \mathrm{~d}$ \\
\hline & \multirow{4}{*}{ M1 } & Rhiz. & $35 \mathrm{e}$ & $46 \mathrm{e}$ & $74 \mathrm{f}$ & $92 \mathrm{e}$ & $0.37 \mathrm{f}$ & $0.47 \mathrm{f}$ \\
\hline & & Azto. & $57 \mathrm{~b}$ & $62 \mathrm{~b}$ & $118 \mathrm{~b}$ & $134 \mathrm{~b}$ & $0.87 \mathrm{~b}$ & $0.93 \mathrm{~b}$ \\
\hline & & PDB & $51 \mathrm{c}$ & $59 \mathrm{c}$ & $110 \mathrm{c}$ & $117 \mathrm{c}$ & $0.77 \mathrm{c}$ & $0.85 \mathrm{c}$ \\
\hline & & Mix & $66 \mathrm{a}$ & $73 \mathrm{a}$ & 138 a & $173 \mathrm{a}$ & $1.20 \mathrm{a}$ & $1.23 \mathrm{a}$ \\
\hline
\end{tabular}


The second 2-factor interaction in Table 3 belongs to organic compost $\mathrm{x}$ inoculation with biofertilizers shows that applying compost and inoculating with a mixture of Azotobacter and Bacillus megaterium was superior to all other combination treatments of this interaction. El- Boraie $\boldsymbol{e} t$ al. (2009) and Gharib et al. (2009) who found that the highest significant pod yield was obtained from inoculating the seeds with a mixture of Rhizobium + Azotobacter chroococcum + Bacillus megaterium.

Table 3 shows also the Biomagic $\mathrm{x}$ inoculation on the same traits. Spraying the plants with rich nutrient solution; Biomagic, plus inoculating the seeds with a mixture of Azotobacter chroococcum + Bacillus megaterium significantly gave the highest plant height, plant dry matter production, and nodules weight plant ${ }^{-1}$ in both years of study.

From Table 3, presents the 3-factor interaction on the sametraits. The best treatment includes applying olive compost + inoculating the peanut seeds with a mixture of Azotobacter chroococcum + Bacillus megaterium.

Effects of applied treatments on seed yield.plant ${ }^{-1}$, seed oil content $(\%)$, seed protein content $(\%), P$ content in seeds $(\%)$, and $K$ content in seeds $(\%)$

Table 4 shows how every source of variance among the applied treatments could translate its potential that was uncovered in tables 2 and 3 into seed yield.plant ${ }^{-1}$, seed oil content.plant ${ }^{-1}$, protein content.plant ${ }^{-1}, \mathrm{P}$ content in seeds.plant ${ }^{-1}$, and $\mathrm{K}$ content in seeds.plant ${ }^{-1}$ in the peanut growth seasons of 2015 and 2016. So, obviously seen is that the application of olive residues compost was evidently better than no application. So was the case with spraying Biomagic nutrient solution on peanut plants' canopy, spraying was evidently better than non-spraying on the five measured traits depicted in Table 4.

From among the four biological inoculation treatments, inoculating the seeds with a mixture of Azotobacter chroococcum and Bacillus megaterium proved to be the best. In addition, this treatment was significantly better than inoculating the seeds with Rhizobium. In the current research work Azotobacter could be elaborated in conjunction with the application of olive waste compost to wean peanut plants toward better growth parameters and then seed yield with better quality.

Table 4 depicts also the organic $\mathrm{x}$ Biomagic interaction for which the application of compost with spraying with Biomagic was the best combination treatment of this interaction on seed yield.plant ${ }^{-1}$, seed oil content.plant $^{-1}$, protein content.plant ${ }^{-1}, \mathrm{P}$ content in seeds.plant ${ }^{-1}$, and $\mathrm{K}$ content in seeds.plant ${ }^{-1}$ in 2015 and 2016.

The second 2-factor interaction mentioned in Table 4 belongs to the $\mathrm{OM} \times \mathrm{I}$. Albeit obvious from the data, it deserves mentioning that the best combination treatment is applying compost with inoculating the seeds with a mixture of Azotobacter and PDB in both years of study. 
Table 4. Influence of the applied treatments on seed weight.plant ${ }^{-1}$, seed oil \%, seed protein \%, seed P \%, and seed K \% in 2015 and 2016 at Balouza, North Sinai, Egypt.

\begin{tabular}{|c|c|c|c|c|c|c|c|c|c|c|c|c|}
\hline \multirow{2}{*}{\multicolumn{2}{|c|}{ Variables }} & \multirow[t]{2}{*}{ Treatment } & \multicolumn{2}{|c|}{$\begin{array}{l}\text { Seed weight. } \\
\text { plant }^{-1}\end{array}$} & \multicolumn{2}{|c|}{ Seed oil \% } & \multicolumn{2}{|c|}{$\begin{array}{c}\text { Seed protein } \\
\%\end{array}$} & \multicolumn{2}{|c|}{ Seed P \% } & \multicolumn{2}{|c|}{ Seed K \% } \\
\hline & & & 2015 & 2016 & 2015 & 2016 & 2015 & 2016 & 2015 & 2016 & 2015 & 2016 \\
\hline \multirow{2}{*}{\multicolumn{2}{|c|}{ OM }} & 0 & $36 \mathrm{~b}$ & $40 \mathrm{~b}$ & $36 \mathrm{~b}$ & $37 \mathrm{~b}$ & $14 \mathrm{~b}$ & $15 \mathrm{~b}$ & $0.15 \mathrm{~b}$ & 0.17 b & $1.22 \mathrm{~b}$ & $1.27 \mathrm{~b}$ \\
\hline & & 1 & $65 \mathrm{a}$ & $70 \mathrm{a}$ & $43 a$ & $44 a$ & 20 a & 21 a & 0.32 a & 0.35 a & $1.51 \mathrm{a}$ & $1.64 \mathrm{a}$ \\
\hline \multirow{2}{*}{\multicolumn{2}{|c|}{ M }} & $\mathbf{0}$ & $42 \mathrm{~b}$ & $46 \mathrm{~b}$ & 39 a & $40 \mathrm{~b}$ & $16 \mathrm{~b}$ & $17 \mathrm{~b}$ & $0.21 \mathrm{~b}$ & $0.24 \mathrm{~b}$ & $1.26 \mathrm{~b}$ & $1.35 \mathrm{~b}$ \\
\hline & & 1 & $60 \mathrm{a}$ & $64 a$ & $40 \mathrm{a}$ & $42 \mathrm{a}$ & 18 a & 19 a & $0.26 \mathrm{a}$ & $0.28 \mathrm{a}$ & $1.47 \mathrm{a}$ & $1.57 \mathrm{a}$ \\
\hline \multirow{4}{*}{\multicolumn{2}{|c|}{ I }} & Rhizo. & $42 d$ & $45 d$ & $36 \mathrm{c}$ & $37 \mathrm{c}$ & $15 \mathrm{c}$ & $15 \mathrm{c}$ & $0.19 \mathrm{c}$ & $0.22 \mathrm{c}$ & $1.19 \mathrm{~d}$ & $1.26 \mathrm{~d}$ \\
\hline & & Azto. & $50 \mathrm{~b}$ & $55 \mathrm{~b}$ & $40 \mathrm{~b}$ & $41 \mathrm{~b}$ & $17 \mathrm{~b}$ & $18 \mathrm{~b}$ & $0.24 \mathrm{~b}$ & $0.27 \mathrm{~b}$ & $1.42 \mathrm{~b}$ & $1.46 \mathrm{~b}$ \\
\hline & & PDB & $46 \mathrm{c}$ & $51 \mathrm{c}$ & 38 bc & $40 \mathrm{~b}$ & $16 \mathrm{bc}$ & 17 bc & $0.23 \mathrm{~b}$ & $0.25 \mathrm{~b}$ & $1.31 \mathrm{c}$ & $1.40 \mathrm{c}$ \\
\hline & & Mix & $65 a$ & $69 \mathrm{a}$ & $44 a$ & $46 \mathrm{a}$ & 20 a & $21 \mathrm{a}$ & 0.28 a & 0.31 a & $1.55 \mathrm{a}$ & $1.71 \mathrm{a}$ \\
\hline \multirow{4}{*}{\multicolumn{2}{|c|}{ OMxM }} & 0x0 & $30 \mathrm{~d}$ & $33 \mathrm{~d}$ & $35 \mathrm{~b}$ & $37 \mathrm{~b}$ & $13 \mathrm{c}$ & $14 \mathrm{c}$ & 0.14 c & $0.16 \mathrm{c}$ & $1.16 \mathrm{~d}$ & $1.23 \mathrm{~d}$ \\
\hline & & 0x1 & $42 \mathrm{c}$ & $47 \mathrm{c}$ & $37 \mathrm{~b}$ & $38 \mathrm{~b}$ & $14 \mathrm{c}$ & $15 \mathrm{c}$ & $0.17 \mathrm{c}$ & $0.19 \mathrm{c}$ & $1.28 \mathrm{c}$ & $1.31 \mathrm{c}$ \\
\hline & & $1 \times 0$ & $53 \mathrm{~b}$ & $58 \mathrm{~b}$ & $42 \mathrm{a}$ & $43 a$ & $18 \mathrm{~b}$ & $19 \mathrm{~b}$ & $0.28 \mathrm{~b}$ & $0.33 \mathrm{~b}$ & $1.37 \mathrm{~b}$ & $1.46 \mathrm{~b}$ \\
\hline & & $1 \times 1$ & $79 a$ & 81 a & $44 a$ & 45 a & 22 a & $22 a$ & 0.36 a & 0.37 a & $1.66 \mathrm{a}$ & $1.83 \mathrm{a}$ \\
\hline \multirow{8}{*}{\multicolumn{2}{|c|}{ OMxI }} & 0xRh & $30 \mathrm{~g}$ & $33 \mathrm{~g}$ & $34 \mathrm{e}$ & $35 \mathrm{e}$ & $13 \mathrm{e}$ & $13 \mathrm{e}$ & $0.13 \mathrm{e}$ & $0.15 \mathrm{f}$ & $1.08 \mathrm{~g}$ & $1.13 \mathrm{~h}$ \\
\hline & & 0xAzo. & $37 \mathrm{f}$ & $41 \mathrm{f}$ & 36 de & $37 \mathrm{e}$ & $13 \mathrm{de}$ & $14 \mathrm{e}$ & $0.15 \mathrm{e}$ & 0.18 de & $1.27 \mathrm{e}$ & $1.28 \mathrm{f}$ \\
\hline & & 0xPDB & $35 \mathrm{f}$ & $40 \mathrm{f}$ & 36 de & $37 \mathrm{e}$ & $13 \mathrm{e}$ & $14 \mathrm{e}$ & $0.15 \mathrm{e}$ & 0.17 ef & $1.18 \mathrm{f}$ & $1.23 \mathrm{~g}$ \\
\hline & & 0xMix & $42 \mathrm{e}$ & $47 \mathrm{e}$ & $39 \mathrm{c}$ & $41 \mathrm{~cd}$ & $16 \mathrm{~cd}$ & $17 \mathrm{~d}$ & $0.18 \mathrm{~d}$ & $0.20 \mathrm{~d}$ & $1.37 \mathrm{~d}$ & $1.43 \mathrm{~d}$ \\
\hline & & 1xRh. & $55 \mathrm{~d}$ & $57 \mathrm{~d}$ & $39 \mathrm{c}$ & $40 \mathrm{~d}$ & $17 \mathrm{c}$ & $18 \mathrm{~cd}$ & $0.26 \mathrm{c}$ & $0.28 \mathrm{c}$ & $1.30 \mathrm{e}$ & $1.38 \mathrm{e}$ \\
\hline & & 1xAzo. & $63 \mathrm{~b}$ & $69 \mathrm{~b}$ & $43 \mathrm{~b}$ & $44 \mathrm{~b}$ & $20 \mathrm{~b}$ & $21 \mathrm{~b}$ & $0.33 \mathrm{~b}$ & $0.36 \mathrm{~b}$ & $1.57 \mathrm{~b}$ & $1.63 \mathrm{~b}$ \\
\hline & & 1XPDB & $58 \mathrm{c}$ & $62 \mathrm{c}$ & 41 bc & 43 bc & $19 \mathrm{~b}$ & 20 bc & 0.31 b & $0.34 \mathrm{~b}$ & $1.45 \mathrm{c}$ & $1.57 \mathrm{c}$ \\
\hline & & 1xMix & 88 a & $90 \mathrm{a}$ & 49 a & 50 a & $24 a$ & 25 a & 0.38 a & $0.42 \mathrm{a}$ & $1.74 \mathrm{a}$ & $1.98 \mathrm{a}$ \\
\hline \multirow{8}{*}{\multicolumn{2}{|c|}{ M x I }} & 0xRh. & $35 \mathrm{~g}$ & $37 \mathrm{~g}$ & $35 \mathrm{e}$ & $36 \mathrm{e}$ & $14 \mathrm{f}$ & $15 \mathrm{f}$ & $0.18 \mathrm{~g}$ & $0.20 \mathrm{~g}$ & $1.10 \mathrm{~h}$ & $1.17 \mathrm{~g}$ \\
\hline & & 0xAzo. & $41 \mathrm{e}$ & $47 \mathrm{e}$ & 39 cd & $41 \mathrm{c}$ & $16 d$ & $17 \mathrm{~d}$ & $0.21 \mathrm{e}$ & $0.25 \mathrm{~d}$ & $1.30 \mathrm{e}$ & $1.37 \mathrm{~d}$ \\
\hline & & 0XPDB & $38 \mathrm{f}$ & $43 \mathrm{f}$ & $38 \mathrm{~d}$ & $40 \mathrm{~cd}$ & $15 \mathrm{e}$ & $16 \mathrm{e}$ & $0.20 \mathrm{f}$ & $0.24 \mathrm{e}$ & $1.21 \mathrm{~g}$ & $1.30 \mathrm{f}$ \\
\hline & & 0xMix & $53 \mathrm{c}$ & $56 \mathrm{~cd}$ & $42 \mathrm{~b}$ & $44 \mathrm{~b}$ & $18 \mathrm{~b}$ & $19 \mathrm{~b}$ & $0.25 \mathrm{~d}$ & $0.29 \mathrm{~b}$ & $1.45 \mathrm{c}$ & $1.55 \mathrm{~b}$ \\
\hline & & 1xRh. & $50 \mathrm{~d}$ & $53 \mathrm{~d}$ & $38 \mathrm{~d}$ & $39 \mathrm{~d}$ & $16 d$ & $16 \mathrm{e}$ & $0.21 \mathrm{e}$ & $0.23 \mathrm{f}$ & $1.28 \mathrm{f}$ & $1.35 \mathrm{e}$ \\
\hline & & 1 xAzo. & $59 \mathrm{~b}$ & $63 \mathrm{~b}$ & $40 \mathrm{c}$ & $41 \mathrm{c}$ & $18 \mathrm{~b}$ & $18 \mathrm{c}$ & 0.27 b & $0.29 \mathrm{~b}$ & $1.53 \mathrm{~b}$ & $1.55 \mathrm{~b}$ \\
\hline & & 1Xpdb & $55 \mathrm{c}$ & $59 \mathrm{c}$ & 39 cd & $40 \mathrm{~cd}$ & $17 \mathrm{c}$ & $18 \mathrm{c}$ & $0.26 \mathrm{c}$ & $0.27 \mathrm{c}$ & $1.42 \mathrm{~d}$ & $1.50 \mathrm{c}$ \\
\hline & & 1xMix & $78 \mathrm{a}$ & 81 a & $46 a$ & $47 a$ & 22 a & 22 a & 0.31 a & 0.33 a & $1.66 \mathrm{a}$ & $1.87 \mathrm{a}$ \\
\hline \multirow{8}{*}{ OM0 } & \multirow{4}{*}{ M0 } & Rhiz. & 221 & $23 \mathrm{k}$ & $33 \mathrm{f}$ & $33 \mathrm{~h}$ & $12 \mathrm{~g}$ & $13 \mathbf{i}$ & $0.12 \mathrm{i}$ & $0.14 k$ & $1.02 \mathrm{l}$ & $1.07 \mathrm{k}$ \\
\hline & & Azto. & $31 \mathrm{k}$ & $36 \mathrm{j}$ & $36 \mathrm{e}$ & $37 \mathrm{~g}$ & $13 \mathrm{fg}$ & $14 \mathrm{~h}$ & 0.14 hi & 0.16 ij & $1.20 \mathrm{i}$ & $1.27 \mathrm{i}$ \\
\hline & & PDB & $30 \mathrm{k}$ & $34 \mathrm{j}$ & 35 ef & $36 \mathrm{~g}$ & $13 \mathrm{fg}$ & $14 \mathrm{~h}$ & $0.13 \mathrm{i}$ & $0.15 \mathrm{jk}$ & $1.12 \mathrm{k}$ & $1.20 \mathrm{j}$ \\
\hline & & Mix & $38 \mathrm{j}$ & $41 \mathrm{i}$ & $37 \mathrm{e}$ & $39 \mathrm{f}$ & 15 def & $16 f$ & $0.17 \mathrm{~g}$ & $0.19 \mathrm{gh}$ & $1.30 \mathrm{~g}$ & $1.40 \mathrm{~g}$ \\
\hline & \multirow{4}{*}{ M1 } & Rhiz. & $38 \mathbf{j}$ & $43 \mathrm{hi}$ & 35 ef & $36 \mathrm{~g}$ & $13 \mathrm{fg}$ & $14 \mathrm{~h}$ & 0.14 hi & $0.16 \mathrm{ij}$ & $1.13 \mathrm{k}$ & $1.20 \mathrm{j}$ \\
\hline & & Azto. & $43 \mathrm{hi}$ & $47 \mathrm{~g}$ & $37 \mathrm{e}$ & $37 \mathrm{~g}$ & 14 efg & $15 \mathrm{~g}$ & $0.17 \mathrm{~g}$ & $0.19 \mathrm{gh}$ & $1.33 \mathrm{f}$ & $1.30 \mathrm{~h}$ \\
\hline & & PDB & $40 \mathrm{ij}$ & $45 \mathrm{gh}$ & $36 \mathrm{e}$ & $37 \mathrm{~g}$ & $13 \mathrm{fg}$ & $14 \mathrm{~h}$ & $0.16 \mathrm{gh}$ & 0.18 hi & $1.23 \mathrm{~h}$ & $1.27 \mathrm{i}$ \\
\hline & & Mix & $46 \mathrm{gh}$ & $53 \mathrm{f}$ & $40 \mathrm{~d}$ & $42 \mathrm{de}$ & $17 \mathrm{~cd}$ & $18 d$ & $0.20 \mathrm{f}$ & $0.21 \mathrm{~g}$ & $1.43 \mathrm{~d}$ & $1.47 \mathrm{f}$ \\
\hline \multirow{8}{*}{ OM1 } & \multirow{4}{*}{ M0 } & Rhiz. & $48 \mathrm{fg}$ & $51 \mathrm{f}$ & $37 \mathrm{e}$ & $39 \mathrm{f}$ & 16 cde & $17 \mathrm{e}$ & $0.23 \mathrm{e}$ & $0.27 \mathrm{f}$ & $1.17 \mathrm{j}$ & $1.27 \mathrm{i}$ \\
\hline & & Azto. & $51 \mathrm{f}$ & $58 \mathrm{e}$ & $43 \mathrm{c}$ & $44 \mathrm{c}$ & $18 \mathrm{c}$ & $19 \mathrm{c}$ & $0.29 \mathrm{~d}$ & $0.34 \mathrm{de}$ & $1.40 \mathrm{e}$ & $1.47 \mathrm{f}$ \\
\hline & & PDB & $46 \mathrm{gh}$ & $51 f$ & $41 \mathrm{~d}$ & $43 \mathrm{~cd}$ & $18 \mathrm{c}$ & $18 \mathrm{~d}$ & $0.27 \mathrm{~d}$ & 0.32 e & $1.30 \mathrm{~g}$ & $1.40 \mathrm{~g}$ \\
\hline & & Mix & $67 d$ & $72 \mathrm{c}$ & $47 \mathrm{~b}$ & $48 \mathrm{~b}$ & $21 \mathrm{~b}$ & $22 \mathrm{~b}$ & $0.34 \mathrm{c}$ & $0.39 \mathrm{~b}$ & $1.60 \mathrm{c}$ & $1.70 \mathrm{~d}$ \\
\hline & \multirow{4}{*}{ M1 } & Rhiz. & $61 \mathrm{e}$ & $63 d$ & $40 \mathrm{~d}$ & $41 \mathrm{e}$ & $18 \mathrm{c}$ & $19 \mathrm{c}$ & $0.28 \mathrm{~d}$ & $0.29 \mathrm{f}$ & $1.43 \mathrm{~d}$ & $1.50 \mathrm{e}$ \\
\hline & & Azto. & $76 \mathrm{~b}$ & $80 \mathrm{~b}$ & $43 c$ & $44 \mathrm{c}$ & $22 b$ & $22 \mathrm{~b}$ & $0.37 \mathrm{~b}$ & 0.38 bc & $1.73 \mathrm{~b}$ & $1.80 \mathrm{~b}$ \\
\hline & & PDB & $71 \mathrm{c}$ & $72 \mathrm{c}$ & $41 d$ & 42 de & $21 \mathrm{~b}$ & $22 \mathrm{~b}$ & 0.35 bc & $0.36 \mathrm{~cd}$ & $1.60 \mathrm{c}$ & $1.73 \mathrm{c}$ \\
\hline & & Mix & 109 a & 109 a & 51 a & 52 a & $26 a$ & $27 \mathrm{a}$ & $0.43 \mathrm{a}$ & $0.45 \mathrm{a}$ & $1.88 \mathrm{a}$ & $2.27 \mathrm{a}$ \\
\hline
\end{tabular}

The third interaction of $\mathrm{M} \times \mathrm{I}$ treatments revealed in Table 4 that the best combination treatment of this interaction was due to spraying Biomagic with inoculating the seeds with a mixture of Azotobacter and PDB in both years of study.

For the one 3-factor interaction which belong to applying OM x M x I, Table 4 shows that the best combination treatment was composed from applying compost + spraying plants' canopy with Biomagic $\mathrm{x}$ inoculating the seeds with a mixture of Azotobacter and PDB in both years of study. 


\section{REFERENCES}

Abdel-Hafez, A.M. (1966). Some studies on acid producing microorganisms in soil and rhizosphere with special reference to phosphate dissolvers. Ph.D. Thesis, Fac. of Agric., Ain Shams Univ., Cairo, Egypt.

Abdel-Malek, Y. and Y. Z. Ishac (1968). Evaluation of methods used in counting Azotobacter. J. APPL. Bacteriol, 31:26.

Abou-El-Nour, E.A.A. (2002). Can supplemented potassium foliar feeding reduce the recommended soil potassium? Pak. J. Biol.Sci., 5(3): 259-262.

Ahmed, M.K. ; A.A.O.M. Saad ; A.T. Thalooth and M.O. Kabesh (1997). Utilization of biofertilizers in yield crops production. 10- Yield response of groundnut to inorganic, organic and biofertilizers. Annals Agric. Sci. Ain Shams Univ. Cairo, 42(2): 365-375.

Allen, I.N. (1959). Experiments in soil bacteriology. Burgess Publishing Co., Minneapolis, Minnesota, U.S.A.

Balasubramanian P. and S.P. Palaniappan (1994). Time of NK application and its effect on irrigated groundnut. Madras Agric. J., 83(12): 750- 753.

Bremner, J.M. and C.S. Mulvaney (1982). Nitrogen. In: Page, A.L., Miller, R.H. and Keeney, D.R. (Eds.), Methods of soil analysis. Part 2, Chemical and microbiological properties. Agronomy 9, Soc. Agron., Madison, Wisconsin, pp: 595-624.

Cappuccino, J.C. and N. Sherman (1992). In: Microbiology: A Laboratory Manual, New York, pp. 125-179.

Chandrasekaran, R. ; E. Somasundaram ; M. Amanullah ; K. Nalini ; K. Thirukkumaran and K. Sathyamoorthi (2007). Response of confectionery groundnut (Arachis hypogaea L.) varieties to farm yard manure. J. Appl. Sci. Res., 3(10): 1097-1099.

Cochran, W.G. (1950). Estimation of bacterial densities by mean of the "Most Probable Number". Biometrics, 6: 105-115.

Dharma, A.K. (1996). Organic farming for sustainable agriculture. Agro Botanical Publishers (India), pp. 115-130.

El- Boraie, F.M. ; H.K. Abo-El-Ela and A.M. Gaber (2009). Water Requirements of Peanut Grown in Sandy Soil under Drip Irrigation and Biofertilization. Australian Journal of Basic and Applied Sciences, 3(1): 55-65.

El-Fouly, M.M. and A.A. El-Sayed (1997). Foliar Fertilization: An environmentally friendly application of fertilizers. Dahlia Greidinger International symposium on "Fertilization and Environment" 24-27 March, Haifa, Israel, Ed. John, J. 346-357. 
Gharib, A.A. ; M.M. Shahen and A.A. Ragab (2009). Influence of Rhizobium inoculation combind with Azotobacter chroococcum and Bacillus megaterium var. Phosphaticum on growth , nodulation, yield and quality of two snap bean (Phasealus vulgaris L.) cultivars. $4^{\text {th }}$ Conference on Recent Technologies in Agriculture, 2009.

Hameeda, B. ; G. Harini ; O.P. Rupela ; S.P. Wani and G. Reddy (2008). Growth promotion of maize by phosphate solubilizing bacteria isolated from composts and macrofauna. Microbiol. Res., 163: 234.

Hanan, S.S.; A.M. Safaa ; A.S. Taalab and K.A. Shaban (2015). Evaluation of Nitrogen Levels and Application Methods with or without compost on Yield and Quality of Peanut under the Newly Reclaimed Soils. International Journal of ChemTech Research CODEN (USA): IJCRGG, 8(12): 01-12.

Ismail, S. ; G.U. Malewar ; V.S. Rege and N.V. Yelvikar (1998). Influence of FYM and gypsum on soil properties and yield of groundnut grown in vertisols. Agro Pedol., 8: 73-75.

Jackson, M.L. (1963). Soil chemical analysis. Constable and Comp. Ltd., England.

Mason, J.L. (1963). Flame Photometric Determination of Potassium in Unashed Plant Leaves. Anal. Chem., 35 (7): 874-875.

Piper, C.S. (1950). Soil and plant analysis. Inter science Inc. New York.

Richards, I. A. (1954). Diagnosis and improvement of saline and alkali soils. USDA, Washington, USA, Handbook No. 60.160.

Romero, C. ; M. Brenes ; P. Garcı'a and A. Garrido (2002). Hydroxytyrosol 4-D-glucoside, an important phenolic compound in olive fruits and derived products. J. Agric. Food Chem., 5: 3835-3839.

Subrahmaniyan, K. ; P. Kalaiselvan and N. Arulmozhi (2000). Studies on the effect of nutrient spray and graded level of NPK fertilizers on the growth and yield of groundnut. Intern. J. Trop. Agric., 18(3): 287-290.

Tamer, M.A. (2018). Application of agricultural biotechnology to improve the productivity of Rosemary (Rosmarinus officinalis L.) in sandy soil. Ph. D. Thesis, Fac. Of Sci. Benha Univ. Egypt.

Veeramani, P. ; K. Subrahmaniyan and V. Ganesaraja (2012). OM management on groundnut; A review. Wudpecker Journal of Agricultural Research, 1(7): 238-243.

Watanabe, F.S. and N. Olsen (1965) .Test of an ascorbic acid method for determining phosphorus in soil, water and NaHCO3 extracts from soil. Soil Sci. Soc. Amer. Proc., 29: 677-678. 


\section{الزراعة الحيوية وأثرها على إنتاجية وجودة الفول السودانى تحث ظروف شمال سيناء - مصر \\ محمود علي محمدالسيد}

قسم خصوبة وميكروبيولوجيا الاراضي- مركز بحوث الصحراء

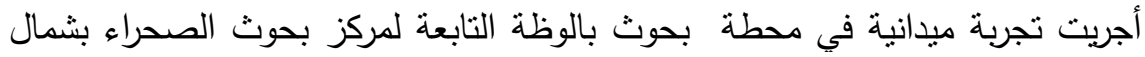

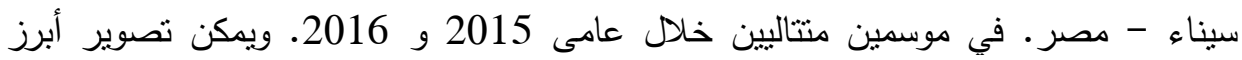

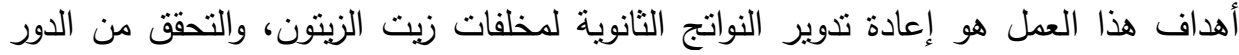

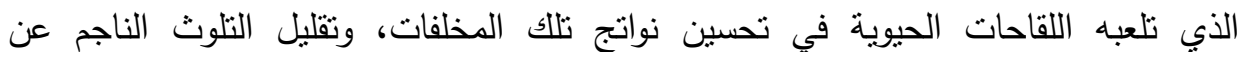
الأستخدام المتزايد من الأسمدة المعدنية ، ودراسة الأهمية الغذائية للسماد الحيوي لنباتات الفول

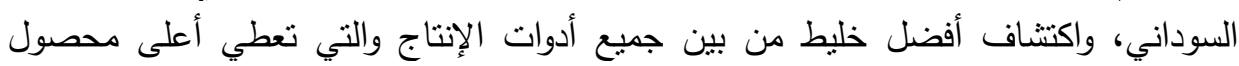

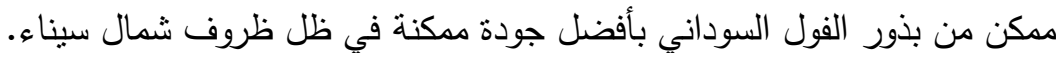

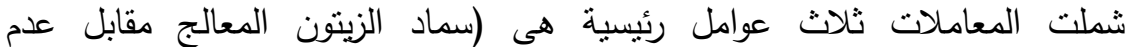

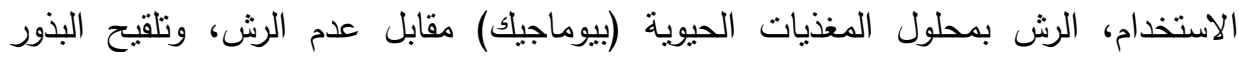
بالأزوتوباكتر والبكتيريا المذيبة للفوسفات، مقابل تلقيح البذور بالريزوبيوم فقط (كنترول) وكلاهما

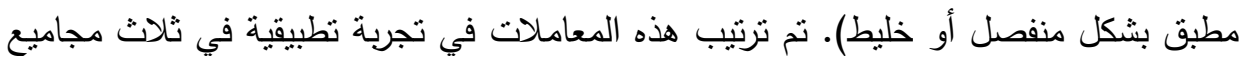
كاملة العشوائية. تم التحقق من القيم المتوسطة من بعضها البعض باستخدام نطاق Dunkan

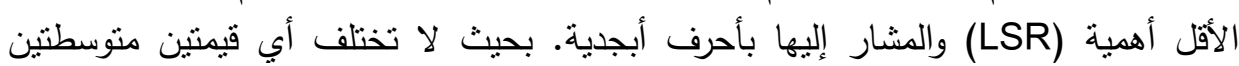

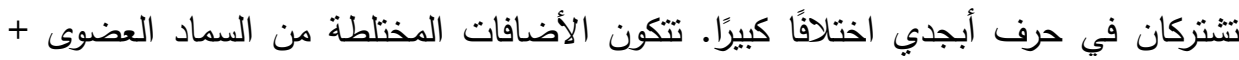

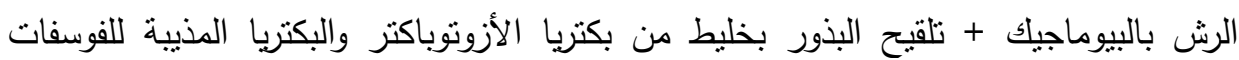

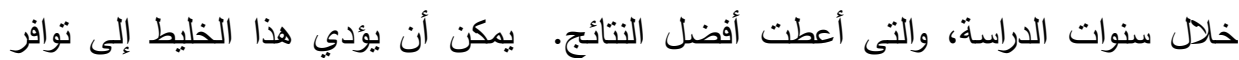
ظروف نمو أفضل بشكل كبير في منطقة الجذور والتي تغذي النمو الميكروبيولوجي الأكثر

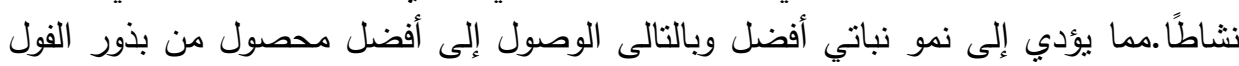
السوداني وبأفضل جودة. 